\title{
Condition of the Coral Reef of Maitara Island Based on Chaetodontidae Fish for Coral Reef Improvement in North Maluku Province
}

\author{
Syahnul Sardi Titaheluw ${ }^{1, *}$, Rovina Andriani ${ }^{2}$, Armain Naim ${ }^{3}$, Raismin Kotta ${ }^{4}$ \\ ${ }^{1}$ Department of Fisheries Product Technology, Faculty of Agriculture, Muhammadiyah University North Maluku, Indonesia \\ ${ }^{2}$ Faculty of Marine Science and Fisheries, Khairun University, Ternate, Indonesia \\ ${ }^{3}$ Department of Fisheries Product Technology, Faculty of Agriculture, Muhammadiyah University North Maluku, Indonesia \\ ${ }^{3}$ Ternate Field Reseach Station, Center for Oceanographic Recearch - Indonesian Institut of Sciences, Indonesia \\ ${ }^{*}$ Corresponden Author, e-mail: titaheluw@gmail.com
}

\begin{abstract}
This study aims to look at the level of damage to coral reefs based on Chaetodontotidae fish and biodiversity of Chaetodontidae fish on Maitara Island. This research was conducted in April to May 2019 at 2 stations. Collecting coral reef data using the Line Intercept Transect (LIT) method which is placed parallel to the shoreline, while Chaetodontidae fish uses the Visual Method Census method. During the study, 20 species of Chaetodontidae were found, representing 2 genera; namely Chaetdon (15 species), and Chelmon (5 types). Fluctuations in the index of diversity, diversity and dominance can be used as indicators of damage to coral reefs. Diversity $\left(\mathrm{H}^{\prime}\right)$ ranges from $0.67-1.01$, the percentage of live coral cover between $10.80 \%$ to $15.30 \%$. The damage of the Coral Reef of Maitara Island is in the damaged category based on the Minister of Environment Decree of 2001. The correlation between the percentage of live coral and Chaetodontidae fish is positive, the determinant coefficient of each species is more than $95 \%$. Low species diversity and individual dominance of one type of Chaetodontidae show that coral reef damage has been caused by anthropic activity, so the loss of most of the main meal of Chaetodontidae fish is coral polyps.
\end{abstract}

Keywords: coral reefs, Chaetodontidae, Maitara Island

\section{INTRODUCTION}

The coral reef ecosystem is a potential food supplier for humans, such as marine organisms such as fish, algae, crustaceans and mollusks can be found in this ecosystem. The presence of various types of biota invites the exploitation of large resources. The activities of coral mining, fishing with talking material and explosives that use non-selective fishing gear and pollution at sea and land are the main problems of degradation. Changes in Environmental Qualifications Regarding Conservation of Coral Reef Resources Biological indicators can be used to measure the level of damage to coral reef ecosystems through the statement of the Chaetodontidae family fish. This type of fish is very dependent on corals as a place to find food and shelter, so its distribution and density is needed by the live coral cover.

Maitara Island is a strategic island in the City of Tidore Islands with a variety of potential natural resources. The existence of this coral reef ecosystem is very important in protecting the island from the interaction of marine dynamics and the people who depend on the economy of coral reefs. The pattern of utilization carried out by the people on Maitara Island so far has not heeded the rules of sustainability, which causes coral reef ecosystems to continue to experience pressure every year and have an impact on society economically and the fish community ecologically and the existence of the island.

[30] The abundance of Chaetodontidae fish in water is strongly influenced by the living coral cover, if the cover is low, the abundance and diversity are also low. This change will affect even tends to be dominated by one particular type.

The relationship between Chaetodontidae fish and coral reefs is caused by several reasons, such as the main food of Chaetodontidae fish is coral polyps and is a typical primary coral inhabitant because life is always associated with coral.

Some similar studies have been carried out in the Maitara Islands, [20] Struktur Komonitas Ikan Karang di Perairan Pulau Maitara, Kota Tidore Kepulauan Provinsi Maluku Utara and [14] Ekosistem Pesisir Ternate, Tidore dan sekitarnya, Provinsi Maluku Utara. In this study, no one has specifically examined the relationship between the Chaetodotntidae fish with coral cover, so this study is an update of information about 
the condition of coral reefs and Chaetodontidae fish on Maitara Island [15], [30], [7], [27], [23], [31], [25] and [9].

\section{METHODS}

This research was conducted in April-May 2019 at 2 Stations (Sari Mauli and Ake Bai). Data collection of coral reefs using the line intercept transect (LIT) method and reef fish using the Visual Census method follows [6].

Retrieval of coral data, roll along the 50 meters stretched along the coastline and then do the recording of corals that are iust

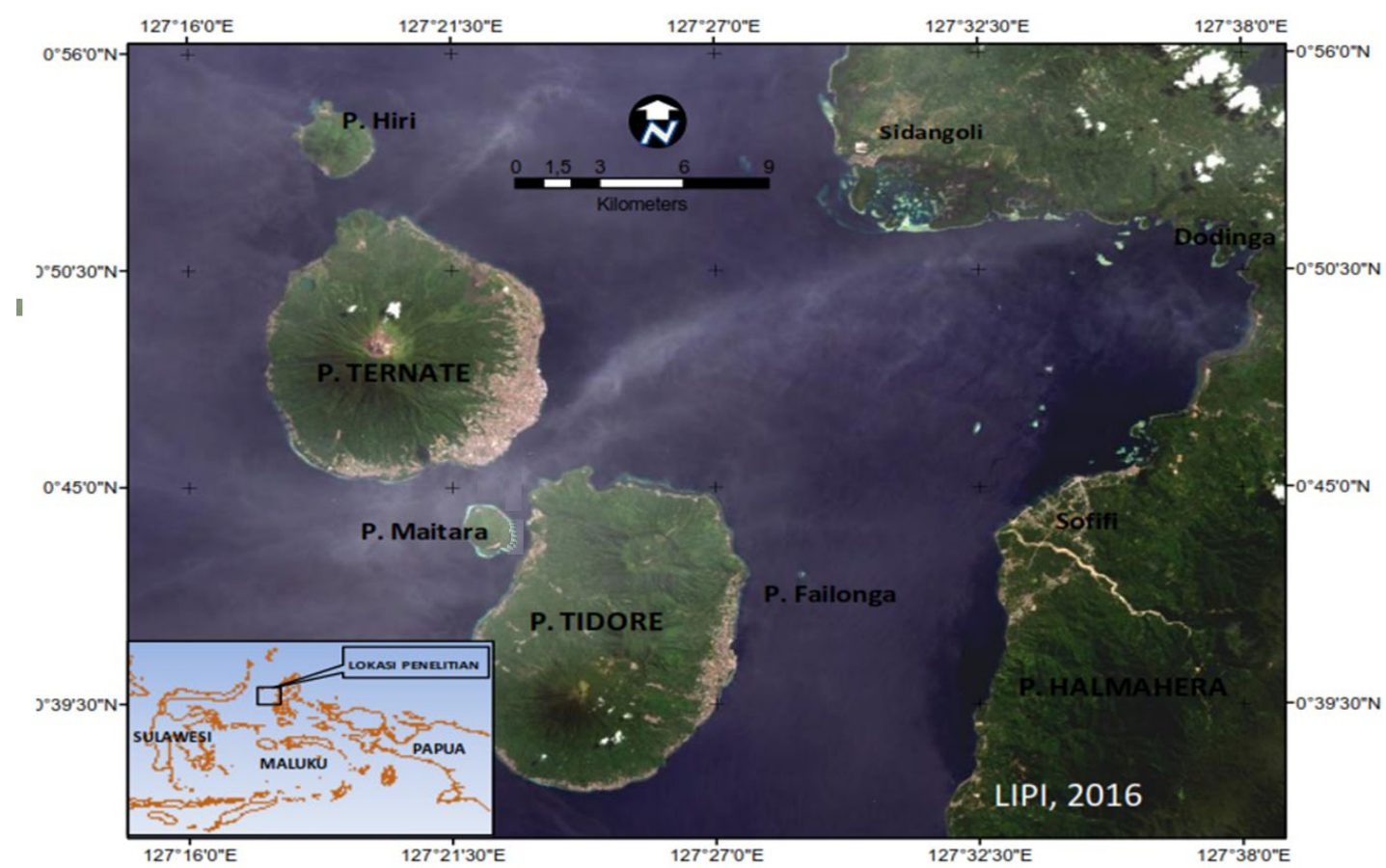

Figure 1. Research Location

Table 1. Equipment used in research

\begin{tabular}{|c|c|}
\hline Tools and Materials & Usability \\
\hline GPS (Global Position System) & For Positioning Station Research \\
\hline SCUBA Diving & Observation of Coral Reef and Fish \\
\hline Rol Meter $(50 \mathrm{~m})$ & Pengukuran transek ikan dan karang \\
\hline Sabak dan Pensil & Recording of coral and fish data \\
\hline Thermometer & Measure the Temperature of the Water \\
\hline Handrefraktometer & Measure Water Salinity \\
\hline Sechi-disc & Measure Visisbility of the Water \\
\hline Drift float & Measure Speed and Direction of The Current \\
\hline Kamera/Video underwater & Dokumentation in the Water \\
\hline Lifefoam Coral and Fish & Indetification Coral and fish \\
\hline
\end{tabular}




\section{Data analysis}

\section{Coral reefs}

The condition of coral reefs is calculated as the percentage of live coral cover. The percentage of live coral is calculated using the equation that is surfaced by English et al (1997).

Percent cover $_{i}=\frac{L i}{L} \mathbf{x} \mathbf{1 0 0} \%$

$L i=$ Total length of category, $\mathrm{L}=$ length of Transect, $i=$ observation test

Data on the condition of treated live coral cover was then categorized based on coral reef retention criteria according to the Minister of Environment Decree No. 4 of 2011 (Table 2).

Table 2. Coral Reef assessment criteria

\begin{tabular}{|l|l|}
\hline Persentage of Cover & Rating Category \\
\hline Very good & $75-100 \%$ \\
\hline Good & $50-74,9 \%$ \\
\hline Medim & $25-49,9 \%$ \\
\hline Bad & $0-24,9 \%$ \\
\hline
\end{tabular}

Mortality Analysis

Measurement of coral mortal index to determine the coral mortality ratio. This index shows the magnitude of life change into dead coral. Mortality index measurements using the equation English et al (1997).

$$
M I=\frac{D C}{D C+C C}
$$

$M I=$ Deat Index, DC = Persentage of Deat Reefs, $C C=$ Persentage of live coral

\section{Abundance}

Species abundance is defined as the number of individuals of one type per meter quadrant in each research station. The abundance of Chaetodontidae fish through census visual data collection along 50 meter transects, 5 meters wide. Calculation of fish abundance using equations [22]

$$
N=\frac{\sum_{n=i}^{i} n i}{A}
$$

$N=$ Fish Abudance (ind $\left./ \mathrm{m}^{2}\right), n i=$ number of $i$-type individual fish, $A=$ fish census area, $i=$ observation test

\section{Species Diversity}

Fish diversity describes the species richness of a fish community as seen from the number of species in an area and the number of individuals in each species. Calculation of species diversity using equations [22]

$$
H^{\prime}=-\sum_{n=i}^{i} P i \operatorname{Ln} P i
$$

$\dot{H}=$ Shanon-Wiener diversity Index, $P i=n i / N, n i=$ the number of attendances for individual type $i, N=$ total number of attendances of all types of individuals $i$

\section{Uniformity}

Uniformity describes the size of the number of individuals between species in one community. The more even distribution of individuals between species, the balance of the ecosystem will increase. The smaller the value of E, indicates there is a tendency for one type of fish to dominate at the research station. Uniformity index calculation uses equation [22]

$$
E=\frac{H^{\prime}}{H^{\prime} \max }=\frac{H^{\prime}}{\log _{2} S}
$$

$E=$ Uniformity index, $H^{\prime}=$ Diversity Index, $S=$ number of individuals.

\section{The Relationship of Coral Reefs to Chaetodontidae fish}

The relationship between Chaetodontidae fish and coral reefs was used a simple regression analysis using Excel 2010 program.

\section{RESULTS AND DISCUSSION}

\section{Live Coral Cover}

Percentage of live corals in all research stations based on the Decree of the Minister of Environment No 4 (2001) is in a damaged condition, the percentage of live corals is not more than $20 \%$ at each station (Figure 2).

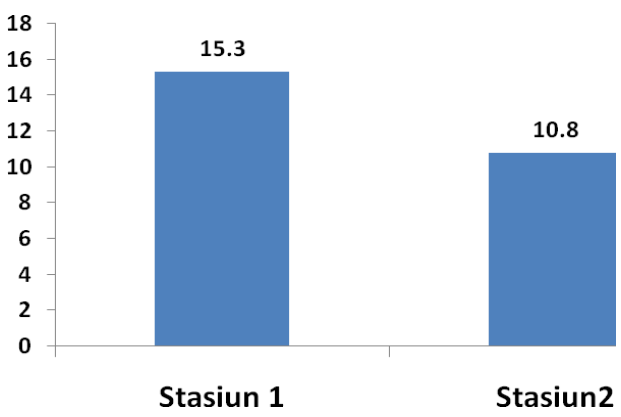

Figure 2. Percentage of live coral

If based on the [14] report, there has been a decline in the percentage of live coral by $25 \%$ within a period of 7 years. The high pressure is not directly proportional to the level of coral growth. The coral growth rate in one year reaches 1.58 $\mathrm{mm} /$ year to $5.38-7.17 \mathrm{~mm} /$ year and porites Indo-Pasific between 0,89-1,23\% in 20-30 year, [8], [4-5], [10] and [29] The coral reefs at the research station experienced considerable pressure caused by anthropogenic activities such as bombing, rock picking, use of anesthesia and bombs. 
The high pressure on coral reefs can be seen from the large percentage as shown in Figure 3.

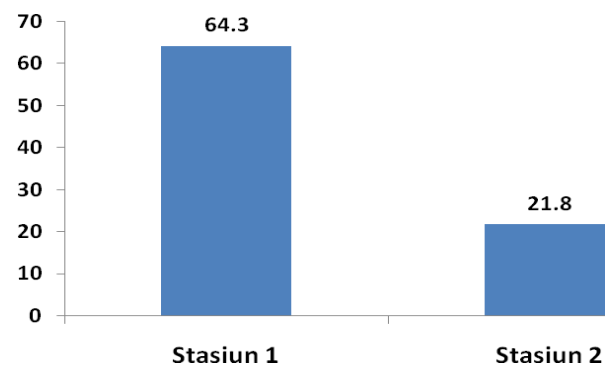

Figure 3. Percentage rock coral

Station 1 is the station with the most pressure. Lack of monitoring factors and community understanding of the role and function of coral reef ecosystems accelerate the process of coral reef degradation on Maitara Island. Because the use of coral reefs by the community does not heed the principles of sustainable management. Factors of supervision and a good understanding of the community will influence behavior in the use of coral reefs.

\section{Indeks Mortalitas}

The high mortality rate at station two is caused by anthropogenic activities. This activity causes a fairly high change in the condition of living coral reefs from good to dead. This also had an impact on the presence of a very small number of Chaetodontidae fish compared to station one. Damage and loss of hard coral cover causes loss of function of coral reefs. [3] the coral reef serves as a place to look for, shelter, enlargement and spawning. Coral reefs are a source of food and bioactive raw materials that are useful in pharmaceuticals and medicine.

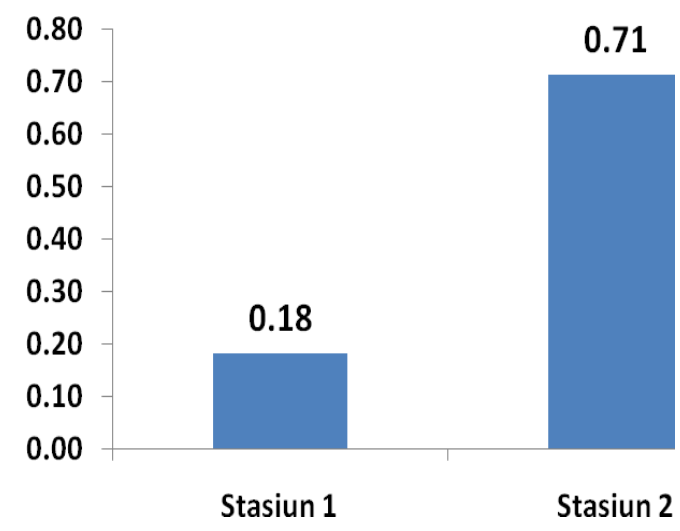

Figure 4. Mortality Rate

\section{Chaetodontidae Fish}

The number of census fishes of Chaetodontidae is 20 species, which are meant in 2 genera. Chaetodon is a genera that dominates at all stations. Not much different from some studies that found the dominance of the Chaetodon genera in the study. [30] found 2 genera in Sidodadi waters and Tegal Island, [1] found 6 genera in Derawan waters, [2] found 3 genera in the waters of Pulau Tikus. The results of the Chaetodontidae fish census found in 2019 are also different from those conducted by [20] finding 4 genera.

Table 3. Number of genera and species of Chaetodontidae fish from several studies in Indonesia

\begin{tabular}{|l|l|l|l|}
\hline Location & Genera & $\begin{array}{l}\text { Spesi } \\
\text { es }\end{array}$ & Reference \\
\hline $\begin{array}{l}\text { Sidodadi dan } \\
\text { Pulau Tegal }\end{array}$ & 2 & 4 & {$[30]$} \\
\hline $\begin{array}{l}\text { Kepulauan } \\
\text { Spermonde }\end{array}$ & 5 & 16 & {$[21]$} \\
\hline Sulawesi Utara & 6 & 32 & {$[1]$} \\
\hline $\begin{array}{l}\text { Biak dan } \\
\text { Kepualaun } \\
\text { Padaido }\end{array}$ & 3 & 28 & {$[11]$} \\
\hline Pulau Makian & 1 & 4 & {$[19]$} \\
\hline Pulau Maitara & 4 & 18 & {$[20]$} \\
\hline Pulau Maitara & 2 & 2 & Research sites \\
\hline
\end{tabular}

When compared with some of the Related studies in Indonesia, the number of genera found on Maitara Island is in the low category. The low genera of the Chaetodontidae fish defy ecological pressure on coral reefs. Decreased coral cover has a large effect on the abundance of Chaetodontidae fish [23], but is also accepted by the pomacentridae family [4].

This study also did not find the presence of Chaetodon trifascialis species which became the species with the highest level of importance to living corals compared to other species. This species is best used among other species as an indicator of coral reefs.

C. Trifascialis is an important indicator for changes in the ecosystem of coral reefs, because loss of coral cover will cause a noticeable decrease in fish abundance not only in Chaetodontidae, but also in other fish needed for coral reefs as a shelter and breed [16], [27] and [7].

C. Kleini is the genus most commonly found at research stations. The high presence of $\mathrm{C}$. kleini is related to the eating habits of Obligate corralivores and high branching coral cover, [1] and [18]. In addition, the location of coral reefs has a different carrying capacity for the presence of Chaetodontidae fish and can be said to be an indicator of cosmopolitanism because it has a wide distribution, [28] and [11]. 
The low abundance index value at station 2 is due to low live coral cover. The low cover of living coral will cause the loss of coral polyps which are the main food of Chaetodontidae. The low percentage of live coral cover directly affects the presence of Chaetodontidae fish found. [30], [15] and [27] Chaetodontidae fish abundance will increase along with an increase in live coral cover because of its fondness for coral polyps. The highest level of Chaetodontidae fish diversity is at station 1 , this is related to the form of utilization of the potential of coral reefs by the community into tourist attractions.

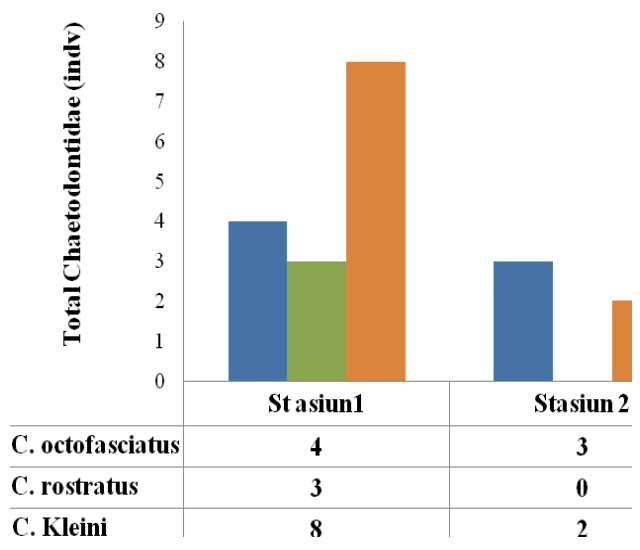

Figure 5. Number of Chaetodontidae fish in Sari Mauli and Ake Bai

Table 4. Maitara Island Chaetodontidae Fish Ecological Index

\begin{tabular}{|l|c|c|}
\hline \multicolumn{1}{|c|}{ Index } & Stasiun 1 & Stasiun 2 \\
\hline Abudance & 0.06 & 0.02 \\
\hline Diversity & 1.01 & 0.67 \\
\hline Uniformity & 1.00 & 1.00 \\
\hline
\end{tabular}

The index value also did not find any potential dominance of one species of Chaetodontidae fish in the waters of Maitara Island. Although there is no potential for Chaetodontidae to dominate at the study site, the diversity and abundance of Chaetodontidae fish found in the low category is caused by the low live coral cover and is the impact of anthropogenic activities.

\section{Relationship between Chaetodontidae and the Condition of Coral Reefs}

One simple analysis in looking at the relationship between Chaetodontidae fish and live coral cover used linear regression. The results of the analysis showed that abundance of Chaetodontidae fish was positively correlated with live coral cover with a coefficient of determination (R2) of 1. The higher the live coral cover, the appearance of Chaetodontidae fish would also increase.

The increasing number of Chaetodontidae fish in a coral reef waters, indicates that the ecosystem condition is still good or good. This condition also indicates that the availability of food is still large and the ecological and economic function of coral reefs is still good.

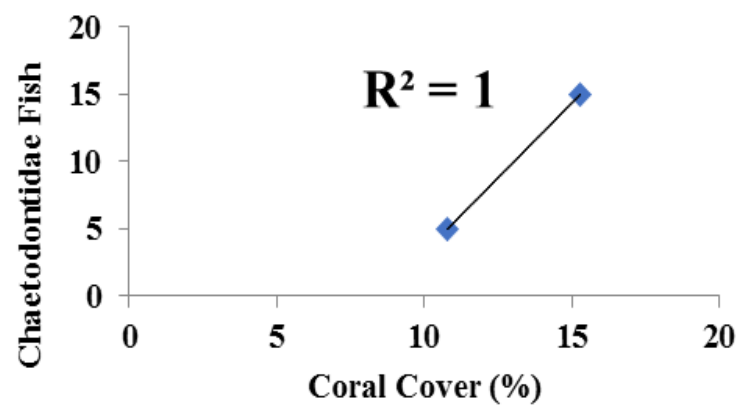

Figure 6. Relationship between Chaetodontidae Fish and coral cover

\section{CONCLUSION}

The condition of the Sari Mauli and Ake Bai coral reefs on Maitara Island has experienced high degradation. The degradation rate in the last 7 years is $25 \%$. The high degradation is not in line with the rate of coral growth in one year which only reaches $1.58-7.17 \mathrm{~mm} /$ year. The degradation rate of coral reefs causes a decrease in the abundance of Chaetodontidae fish due to the reduced availability of food in the form of coral polyps. The number of Chaetodontidae fish found at the study site is the lowest compared to other regions in Indonesia .

\section{REFERENCES}

[1] Adrim M. 2001. Distribusi Spasial Ikan Kepe-Kepe (Suku: Chaetodontidae) Di Wilayah Pesisir Utara Darin Sulawesi Utara. Bidang Sumberdaya Hayati Laut P2O-LIPI Jakarta. 25-34.

[2] Agus Riansyah, Dede Hartono dan Aradea Bujana Kusuma. 2018. Ikan Kepe-Kepe Chaetodontidae) Sebagai Indikator Kerusakan Terumbu Perairan Ekosistem Terumbu Karang Pulau TIkus. Majalah Ilmiah Bilogi Biosfer : A Scientific Journal. 35 (2); 103-110.

[3] Arif Dwi Santisi. 2010. Kondisi Terumbu Karang di Pulau Karang Congkak Kepulauan Seribu. J Hidrosfir Indonesia 5 (2); 73-78.

[4] David A Feary, Marc I. McCormick, Geoffrey P. Jones. 2009. Growth of the reef fishes in respondse 
to live coral cover. Jurnal of Experimental Marine Biology and Ecology.Vol 373, Issue 1.45-49.

[5] Derek P. Manzello. 2010. Coral Growt with thermal stress and ocean acidification: Lessons form the eastern tropical Pasific. Springer. Vol 29, Issue 3. 749-758

[6] English S, Wilkinson C, Baker V. 1997. Survey Manual for Tropical Marine Resources. 2and Edition. Australian Institute of Marine Science. Fownsville: 383 p.

[7] Garry R, Russ. Susannah M. Leahy. 2017. Rapid decline and decadal-scale recovery of corals and Chaetodon butterflyfish on Philippine coral reefs. Marine Biology. 164 (1): 1

[8] Hengki Irawan, Hairunizar dan Arif Pratomo. 2015. Kelangsungan Hidup dan Laju Pertumbuhan karang (Aropora humilis) Hasil Transplantasi Pada Kedalaman Yang Berbeda. Jurnal Kelautan. 1 (1); $1-12$.

[9] Hutomo M \& Adrim M. 1986. Distribution of Reef Fish along Trancects in Bay of Jakarta and Kepulauan Seribu. Mar. sci, 40: 135-156.

[10] Insafitri dan wahyu Andi Nugraha. 2006. Laju Pertumbuhan Karang Porites Lutea. Ilmu Kelautan. 11 (1); 50-53

[11] Jonas Lorwens, 2011. Hubungan antara ikan indikator (chaetodontidae) dan Kondisi karang di pesisir pulau biak dan Kepulauan padaido. J. Lit. Perikan. Ind. Vol 17 (2). 2011.

[12] Krebs, C. J. 1989. Ecological Methodology. New York. NY Harper and Row Publishers Inc. 654p.

[13] Kuiter RH and Tonozaka T. 2001. Pictorial Guide to: Indonesia Reef Fishes. Part 1, 2 and 3. Zoo Netics, Seaford Victoria, Australia.

[14] Lembaga Ilmu Pengetahuan Indonesia. 2012. Ekosistem Pesisir Ternate, Tidore dan Sekitarnya, Provinsi Maluku Utara. LIPI ; Pusat Penelitian Oseanografi, Jakarta. 118 Halaman.

[15] Maduppa HH. 2006. Kajian Ekobiologi Ikan KepeKepe (Chaetodon octofasciatus, BLOCH 1787) Dalam Mendeteksi Kondisi Ekosistem Terumbu Karang Di Pulau Petondan Timur, Kepulauan Seribu, Jakarta. Tesis. Insitut Pertanian Bogor. Bogor.

[16] Maroof Khalaf, Michael P Crosby. 2005. Assemblage structure of butterflyfishes and their use as indicators of Gulf of Aqaba benthic habitat in Jordan. Jurnal Aquatic Conservation. Vol 15 (1): (27-43).

[17] Menteri Negara Lingkungan Hidup. 2001. Kepmen LH No. 4 Tahun 2001 tentang kriteria baku kerusakan terumbu karang.
[18] Muh. Tino Saputra, Baru Sadarun, Rahmadani, Subhan, 2019. Hubungan antara kondisi tutupan karang hidup dengan Kelimpahan ikan chaetodontidae di perairan lalanu, Kecamatan Soropia, Kabupaten Konawe. Sapa Laut. Vol 4 (2): $53-60$

[19] Najamuddin, Samar Ishak, Adityawan Ahmad, 2012. Keragaman ikan karang di perairan Pulau Makian Provinsi Maluku Utara. Depik. 1 (2); 114120.

[20] Nebuchadnezzar Akbar, Firdaut Ismail, Rustam E Paembonan, 2018. Struktur komunitas ikan karang di perairan Pulau Maitara, Kota Tidore Kepulauan. Provinsi Maluku Utara. Jurnal Ilmu Kelautan Kepualauan, 1 (1); 1-14.

[21] Nurjirana dan Andi Ikbal Burhanuddin, 2017. Kelimpahan dan keragaman jenis ikan family Chaetodontidae berdasarkan kondisi tutupan karang Hidup di Kepulauan Spermonde Sulawesi Selatan. Spermonde 2 (3); 34-42.

[22] Odum, E.P. 1993. Fundamentals of Ecology. W.B. Saunders Company, Philadelphia, London. Alih Bahasa oleh: Samingan T. dan B. Srigandono. Gajah Mada University Press. Yogyakarta.

[23] Pratchett M S, Wilson S K and Baird A H 2006 Declines in the abundance of Chaetodon butterflyfishes following extensive coral depletion Journal of Fish Biology 69 1269-80.

[24] Pratchett M. S, Philip L Munday, Shaun K Wilson, Nicolas A. J. Graham, Joshua E. Cinner, David R. Bellwood, Geoffrey P. Jones, Nicholas V.C. Polunin, Tim R. Mcclanahan. 2008. Effect of Climate-Inducet Coral Bleacing on Coral -Reef Fishes Ai Ecological and Economic Consequences. Oceanography and Marine Biology. (46) 251-296

[25] Pratchett M. S, A.H. Bird. D.M. McCowan. D.J. Coker. A.J. Cole. S.K. Wilson. 2008. Protraced declines in coral cover and fish abudance following climate-induced coral bleaching on the Great Barrier Reef. Proceeding of the $11^{\text {th }}$ International Coral Reef Symposium, Ft Lauderdale, Florida 711 July. 1309-1313.

[26] Pratchett M. S, N. A. J. Graham, A. J. Cole. 2013. Specialist corallivores dominate butterflyfish assemblages in coral-dominated reef habitats. Jurnal of Fish Biology; Vol 82 (4) 1177-1191.

[27] Pratchett M. S, S. A. Blowes, D. Coker, E. Kubacki J. Nowicki, A. S. Hoey. 2015. Indirect benefits of high coral cover for non-corallivorous butterflyfishes. Jurnal Coral Reefs. Vol 34 (2): 665-672. 
[28] Rizkie Satriya Utama, Isa Nagib Edrus dan Petrus Christianus Makatipu, 2019. Komunitas Ikan Karang di Pulau Ternate dan Sekitarnya. Oseanologi dan Limnologi Di Indonesia, 4 (1); 5369

[29] Rodrigo Carballo-Ballanos, Derek Soto and Chaulon Allen Chen. 2019. Thermal Stress and Resilience of Coral in a Climate-Changing Word. Jurnal of Marine Science and Engineering. Vol 8, Issue 15. 1-18.
[30] Syahnul Sardi Titaheluw, M Mukhlis Kamal, Yunizar Ernawati. 2015. Hubungan antara ikan Chaetodontidae Dengan Bentuk Pertumbuhan Karang. Agrikan, 8: (1), 77-86.

[31] Zakeria Z.A and Videler, J.J. 2000. Correlation Between the abudance of Butterflyfishes and coral communities in the Southern Red Sea. Vol 1. 487-492. 